\title{
「諸国御関所書付」にみられる近 A PRESENT STATE RESEARCH ON 世関所の現況調査 PREMODERN CHECKPOINTS
}

中田 悟 - $* 1$ 勝又英明 $-* 2$

キーワード :

関所, 復元, 文化財, 史跡

Keywords :

Checkpoint, Restore, Cultural properties, Historic site

\section{Satoru NAKADA $-* 1 \quad$ Hideaki KATSUMATA $-* 2$}

The purpose of this study is to collect basic data for the restore of premodern checkpoints.

For the reason of being lacking in the existence and restore of premodern checkpoints.

(1) The promulgation on the abolition of premodern checkpoints by the Meiji Government.

(2) Most premodern checkpoints were recognized to cultural place in the Showa period.

(3) Development of national highways and rivers for the modernization of trafic.

(4) Most premodern checkpoints were not reused for folk houses by reason of being lacking in the housing function.

\section{1 . 目的}

近世の関所は江戸幕府の政治・交通の面において、極めて高い重 要性を持つ建築物であるにもかかわらず、現在までに建築学的な観 点から、十分な調查及び研究がなされていない。関所の跡地や配置 構成、平面構成など全国の関所を比較・検討された例はない。

このような状況にもかかわらず、関所の復元を実施した地方自治 体が幾つかあるなかで、今後は文化財保護に併せ、近世関所の整備 が地域資源の有効活用による地域個性の形成及び積極的なまちづく りの貴重な足がかりとなることも期待される。そのためにも、現在 の関所跡地の現況調査等の基礎的資料の整理及び考察など関所に関 しての調査・研究は不十分であり、その必要性は高いと言える。

そこで本研究ではこのような状況に着目し、近世関所の整備のた めの基礎的な資料を得ることを目的としている。

\section{2. 研究方法 \\ 2. 1 調査対象}

「諸国御関所書付」"に記載されている近世の関所 53 力所 ${ }^{2)}$ を調査 の対象とし、関所の位置、名所、重要度は図 $4{ }^{3)}$ 及び表 1 に示す。

\section{2 調查方法}

文献調查及び各市町村への教育委員会・文化財保護委員会等への ヒアリング調査及び現地の現況調査（平成 7 年 7 月〜平成 8 年 1 月） を行った。またそれと併せて関所跡地の近隣の方へのヒアリング調 查及びこれらの調査結果の比較・分類を行った。

\section{3. 結果及び考察}

\section{1 現地の確認}

図 1 の通り、53 力所中 47 力所の関所については当時あった場所 を特定することが出来たが、残り 6 力所はおおよその位置はわかる ものの、正確な位置の特定が出来なかった。また現地の確認が出来 た場所でも、当時の関所の教地の領域が正確に確認できる場所はご く少数であった。

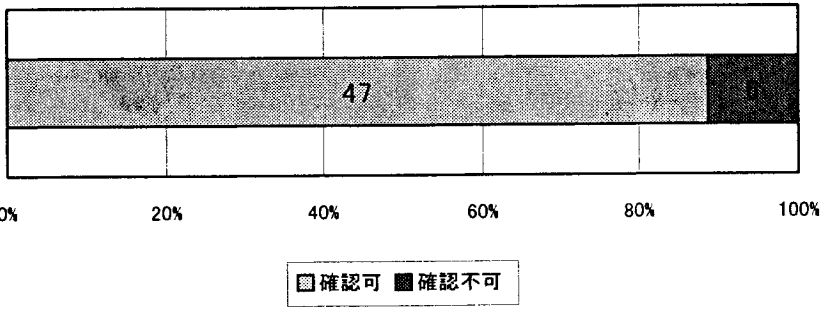

図 1 現地の確認の可·不可

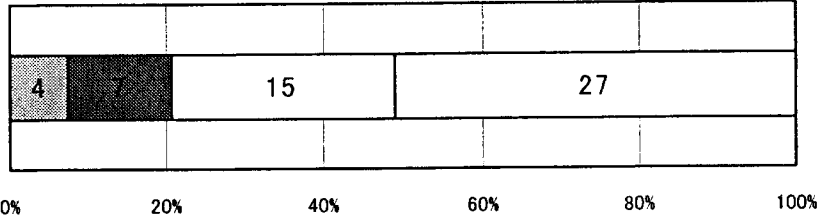

口国指定 都道府紧指定口市町村指定口未指定

図 2 文化財指定の状況

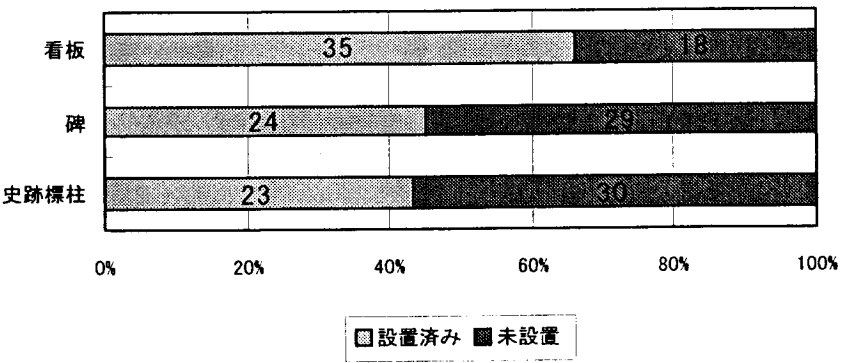

図 3 看板、碑、史跡標柱の設置状況

*1 Nakada Research Institute

*2 Assoc. Prof., Dept. of Architecture, Faculty of Engineering, Musashi Institute of Technology, Dr. Eng. 
表 1 各関所の調査結果

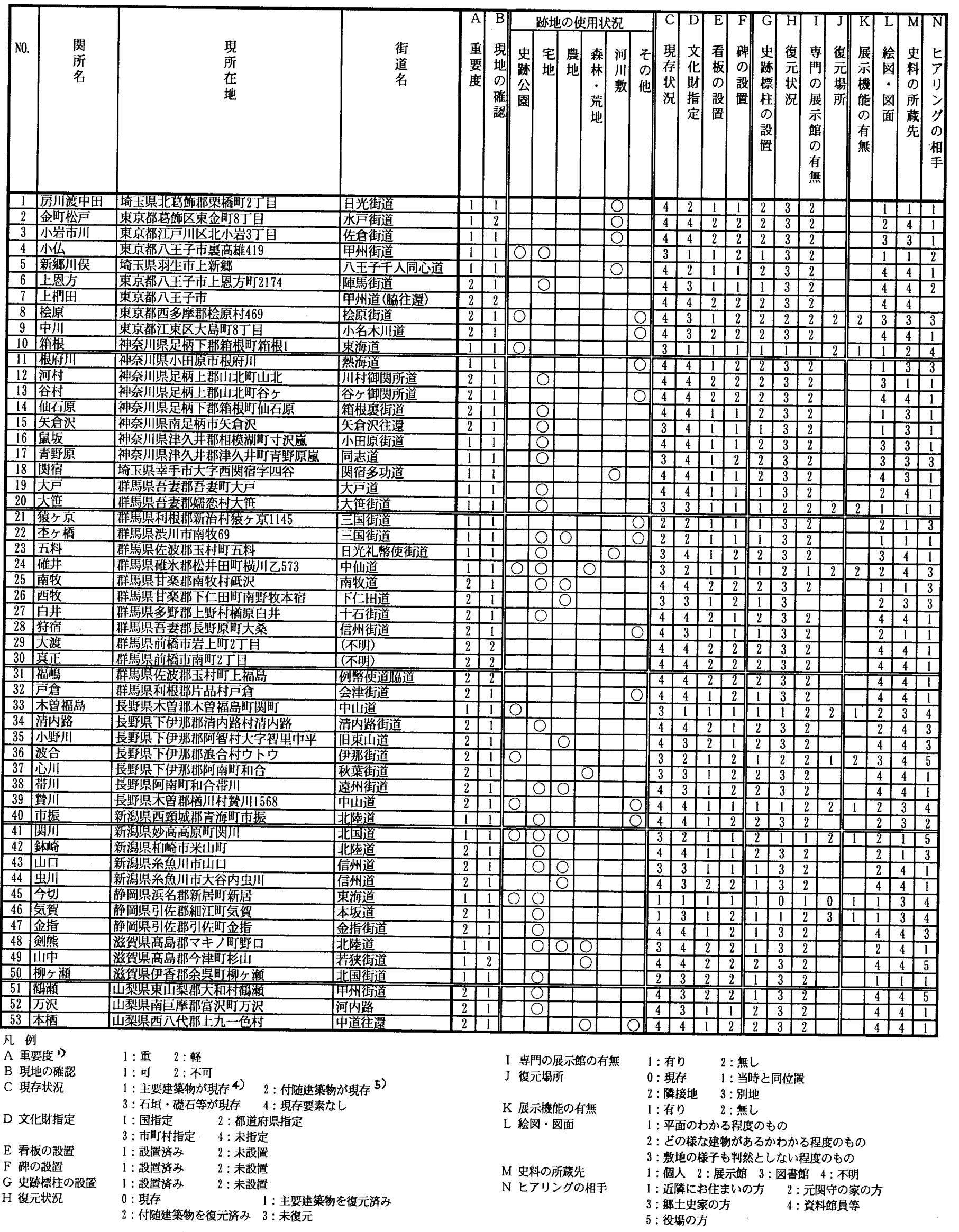




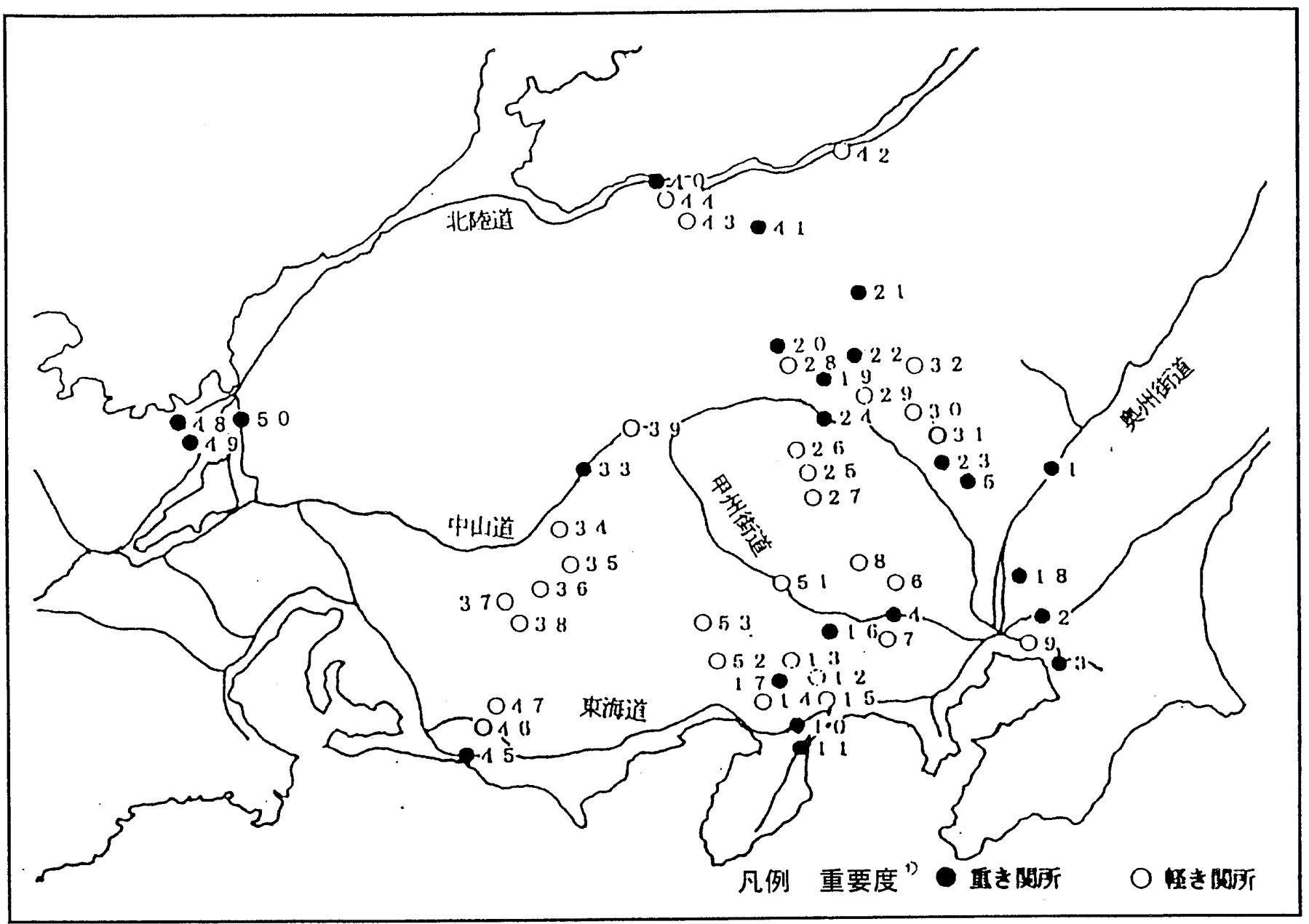

図 4 近世関所所在地

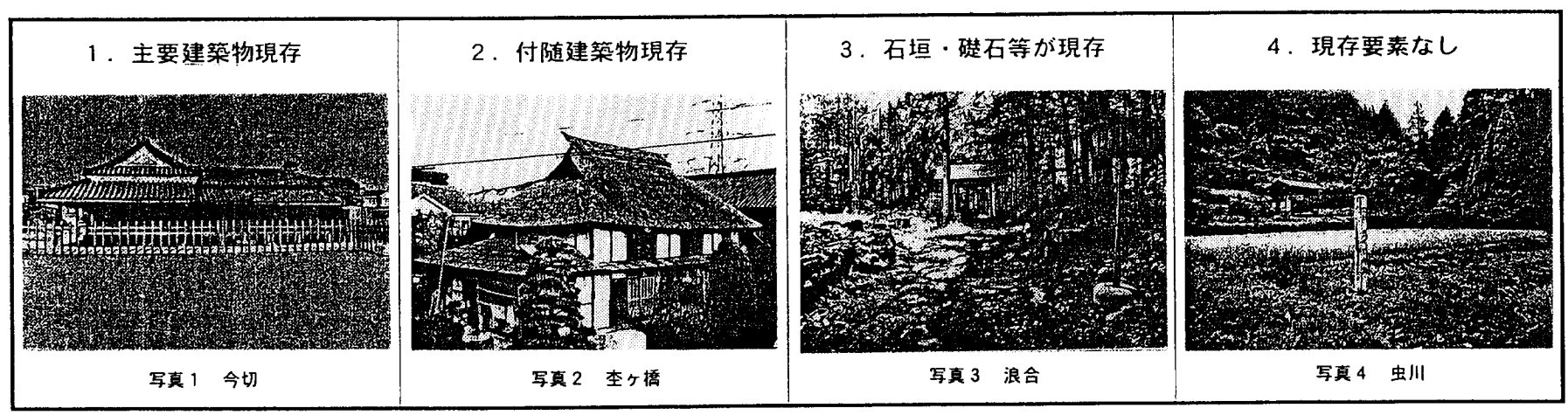

現存状況の例

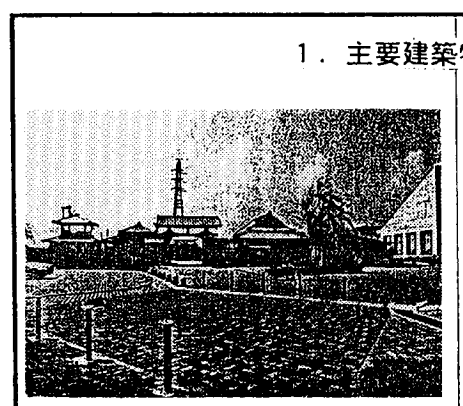

写真 5 気賀

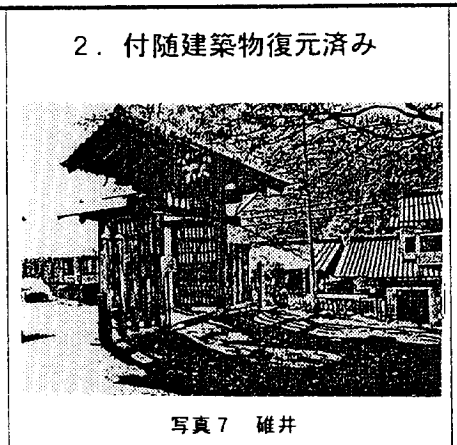

写真 7 碓井
3. 未復元

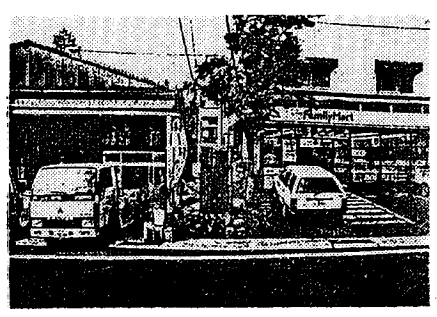

写真 8 仙石原

復元状況の例 


\section{2 史跡としての整備状況}

\section{2. 1 文化財指定}

図 2 の通り、53 力所中 26 力所が史跡もしくは旧跡として文化財 の指定を受けている。しかし、ほとんどのものが昭和になってから の指定であり、すでに当時の様子を伝えるような、はっきりとした 遺構が残っているところは少なくなってしまっている。

\section{2 . 2 看板・碑・史跡標柱の設置}

図 3 の通り、設置状況は過半数以下になっており 、また、いず れかを設置している場所は 53 力所中 42 力所で、残り 11 力所は何も なかった。これは、幹線道路の拡張整備、河川の治水整備に伴い、 主要な街道沿いに整備されていた関所または跡地が収用されたこと によると考えられる。

\section{2. 3 関所跡地の使用状況}

ほとんどの関所跡地は廃関後に民間もしくは地方自治体に払い下 げられたが現在の関所跡地の使用状況は表 1 》に示されるとおりで ある。もっとも関所跡地の使用状況として目を引くのは、宅地で 28 力所と一番多いことである。また、 9 力所は史跡公園として整備さ れているが、地域の人々が史跡に親しむという機能を十分に果たし ているところはさらに少ない。

\section{3 関所の現存状況}

関所の現存状況は図 4 にあるとおりであるが、主要建築物である 本番所が現存しているところは、非常に少ない。当時のままの本番 所を見ることが出来るところは、今切（新居：写真 1 ）のみとなっ てしまっている。 ${ }^{8}$ また、役宅等付随の建築物が現存するのは猿ヶ 京、圭ヶ橋（写真 2 ）、柳ヶ瀨の 3 力所となっている。また、はっき りとした関所の遺構" ${ }^{9}$ が現存しているところも少ない。

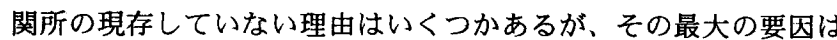
新政府が明治 2 年に全国の関所に廃関の令を公布し取り壊させたこ とである。また、廃関から数十年の間は関所が文化財としての価值 を持つとは考えられなかったことも大きな要因である。

\section{4 復元状況}

現在までに何らかの形で復元がなされているところは図 5 にある 通り、52 力所中（現存している今切は除く） 8 力所である。

復元力所は関門がもっとも多く 8 力所、とくに大笹と碓井（写真

7）では柱や門屝など当時の部材を用いて復元している。

本番所の復元を行っているところ 4 力所となっている。本番所の 復元を行ったところが少ない要因は、正確な図面等の入手が团難で あるこ之、廃関後に敷地が個人等に払い下げられたこと、予算がな いことなどが挙げられる。また、関川（写真 6 ）では平成 9 年に「道 の歴史館整備事業」として復元され、波合（写真 3 ）では平成 4 年 に南門を復元し、本番所の復元を計画中である。

本番所の復元が行われた箱根、木曾福島、賈川、気賀（写真 5 ） ではどれも展示機能 ${ }^{10)}$ を備えており当時の様子を再現したり資料の 展示・解説等を行っている。なお箱根、碓井、今切には独立した専 門の展示館があり資料の展示や当時の旅の道具等の展示がなされて いる。また、ほとんどの関所が関所跡地もしくはその隣接地に復元 しているが、気賀では跡地から $1 \mathrm{~km}$ ほど離れた場所に本番所、向番 所、遠見番所等多くの建築的要素を「ふるさと創生事業」により復 元している。

\section{5 絵図・図面の現存状況とその所藏先}

絵図・図面等についてはもつとも当時の様子を詳しく伝えている ものについての調査結果であるが、これらの絵図・図面等について もすべての史料が公關されているわけでないい。そのために全容を 把握することが困難ではあるが可能な限りの調査を行った。

また、絵図・図面の詳しさについてはばらつきが多いので、表 1 の凡例に示すように間取りが書いてあるもの、どの様な建物がある かわかる程度のもの、関所があることが分かる程度のものの三つに 大別した。

平面の構成がわかる程度に詳細な図面は12 力所でるが、立面等

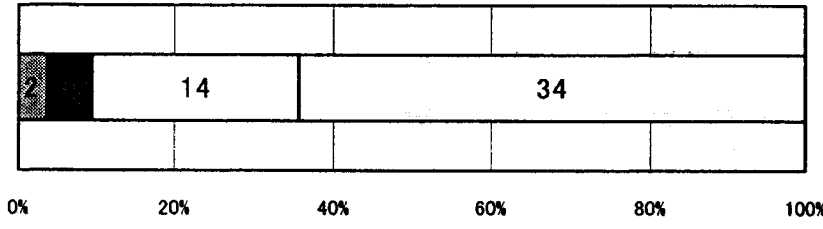

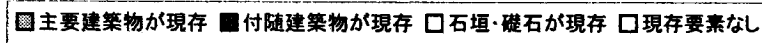

図 5 現存状況

\begin{tabular}{|l|l|l|l|l|l|}
\hline & & & & \\
\hline 4 & \multicolumn{4}{|c|}{44} & \\
\hline & & & & \\
\hline
\end{tabular}

20x

40\%

$60 \%$

$100 \%$

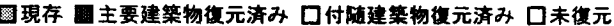

図 6 復元状況

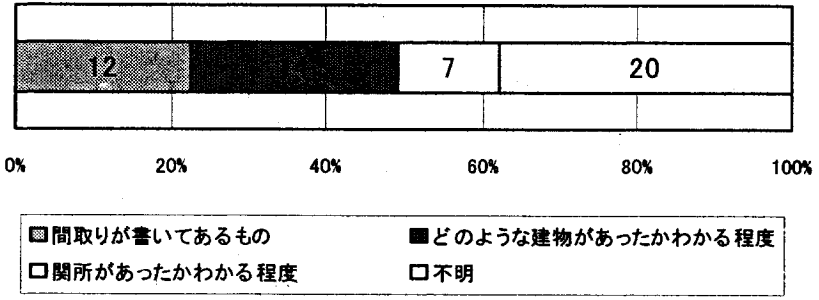

図 7 絵図・図面の内容

が詳しくでているものはない。このことからも関所の復元に関して は極めて不確定な要素が多く、当時のままに、復元することは極め て難しい作業である。

4.まとめ

近世の関所の現存、復元状況及び絵図面等の状況がそしい主な理 由として次のことが挙げられる。

（1）明治政府によって廃関の令が公布された。

（2）昭和になるまで文化財として認知されなかった。

（3）交通インフラの近代化に伴い道路、河川等の整備が進展した。

（4）本番所は住居として機能性に乏しいため転用されなかった。

5 . 今後の課題

（1）口留番所、境目番所、遠見番所の現況調査

(2) 絵図写真等の資料と復元・再現の実態の比較検討

（3）施設の活用の観点から、歷史的に貴重な数少ない現存建物およ び史跡などを文化財として、単に保存を目的にすることに留まらず、 地域の交流の場など積極的な地域住民参加のまちづくりの拠点とし て、ソフト事業を重視した復元及び再現整備が肝要である。

期辞

本調査にあたり貴重な資料のこ提供や、こ指導をしていただいた新居関所資料館切池 殿氏、考現社伊藤裕章氏に感謝いたします。また現地調查の綮に多くの関俰の方々に こ協力頂きました。謸礼申し上げます。

当詥文は加瀬知勇氏の卒業諭文を元に加筆及び监正いたしました。

1) 近世関所制度の研究, pp: 49

18 世紀中期における慕府認可の正式な関所

街道は主要なもののみを乵した。

主要建築物は本番所等の取調機能を持つ建築物を示す。

付随建策物は役宅、門等、注 4)を除く建策物を示す。

史跡案内の看板等にのっていても兒地に何もない場所は除く。

地の使用状況では道路は割爱している。

気賀では本番所の屋根の一部が晛存している。

例えば喽石や石垣の晛存しているもの。

復元された番所等の内部に展示館の機能を持つもの。

文書館等で整理中であったり，图人所有であるため。 参考文献

1）五十望富夫：近世関所制度の研究，有峰書店，1975

2）又英明、加瀨知勇 : 近世関所の現状調査 日本建策学会閶東支部研究報告集 ppl $93 \sim 196,1997.3$

[2001年 4 月20日原稿受理 2001年 7 月27日採用決定］ 